\title{
O IMENSO, FRIÁVEL, REINO DA LINGUAGEM
}

\section{Furio Jesi}

No ensaio que dá título ao seu livro Dietro le parole (Por trás das palavras) (Milano: Garzanti, 1978), Claudio Magris lembra que o reino de Rilke foi até o último instante aquele "imenso e friável" das palavras. O segundo adjetivo pode escandalizar. "Friável": dir-se-ia diminuída, portanto, a suprema destreza do Rilke poeta e prosador ao evocar constelações de palavras através de aparências duras e compactas como as "coisas" perdidas, às quais se direcionavam sua nostalgia e seu medo. Mas, precisamente com esse adjetivo, Magris concentrou em um ponto o esplendor da produção do poeta, dos Die Aufzeichnungen des Malte Laurids Brigge (Os cadernos de Malte Laurids Brigge) às últimas líricas.

As palavras pesadas, quanto mais transparentes, enquanto conferem semblantes cristalinos às páginas de Rilke atuam nelas jogos de espelhos e de desequilíbrios calculados, os quais tornam "friável" todo o reino da palavra e, estando ausente a certeza desse reino, aludem à solidão e à distância.

Em Klingsors letzter Sommer ( $O$ último verão de Klingsor), de Hermann Hesse, dois amigos pintores estão à mesa, diante de "coisas amáveis e reconfortantes: trutas, salmão, aspargos, Chablis, vinho do Valais, Benedictine." Depois, um fala ao outro: "Você tem pintado muitas coisas simpáticas e alegres.. gosto muito de todas: hastes de bandeira, clowns, circos equestres. Mas o que mais me agrada é uma mancha sobre seu carrossel noturno. Você lembra? Sobre a tenda violácea, distante de todas as luzes, alta na noite, agita-se uma pequena bandeira fria, rosa-clara, tão bela, tão fria, tão distante, tão terrivelmente distante de tudo!"

Solidão e distância: em seu livro sobre Joseph Roth, que tem o título mais bonito da ensaística dos últimos anos, Lontano da dove [Distante de onde] (Torino: Einaudi, 1971), Magris diz: "A solidão, isto é, o lirismo, é antes de

L'immenso, friabile, regno del linguaggio.

Riga, Milano, n. 31 (Org. Marco Belpoliti e Enrico Manera), p. 232-233, 2010.

Texto publicado originalmente em L'Ora, Palermo, 21 abr. 1979.

Tradução de Davi Pessoa Carneiro 
tudo distância de toda alteridade, distância absoluta porque desprovida até mesmo de todo ponto de referência e de toda conclusão de procedência: distância de onde." "Distância" é palavra saborosamente rilkeana e é a auréola da "friabilidade" das palavras em que se encontram o poeta de Praga, de língua alemã, incapaz de ser poeta na língua de grupos nacionais eslavos que o fascinam, e os escritores judeus orientais que vivem a cisão entre linguagem e mundo também como perda da única língua sagrada e verdadeira de seus antepassados, ou seja, o hebraico clássico no qual não sabem mais se reconhecer há séculos.

O shtetl, "a pequena cidade" das comunidades judaicas orientais, sobre a qual Magris escreveu páginas esplêndidas, conservava na penumbra do ídiche vozes e nomes de afetos e de "coisas". Com a fuga do shtetl essa penumbra se dilacera e, como Rilke, segundo a leitura de Magris, se penetra "em fraturas e cisões ainda mais profundas" por trás das palavras. São as "fendas que racham a frágil e provisória unidade do eu individual": não por acaso Magris é um especialista em Hoffmann (de Tre studi su Hoffmann, Cisalpino, 1960, ao último livro L'altra ragione. Tre saggi su Hoffmann, Editrice Stampatori, 1978). Em Hoffmann ele reconhece "o isolamento do indivíduo desenraizado da totalidade e a festa do coro transcendental", o instante crucial no qual quem não acredita mais na ratio iluminista "enfrenta a cisão do sujeito... com inflexões alternadas e hesitantes: sempre atento aos resultados das novas ciências noturnas."

O mundo de Hoffmann, diz Magris, "ignora a presença consoladora de universais que garantem o sentido da vida": para Rilke, para os escritores da cultura judaico-oriental, pode-se também falar de universais linguísticos. Magris, por outro lado, funda sua capacidade de colher esses testemunhos de "insensata" distância e solidão em sua pessoal destreza estilística, de grande ensaísta: "Festa, portanto, como metáfora do amor entendido como desejo de identificação, desejo de 'ser você', para usar as palavras com as quais, em clima e em tempos muito diferentes, mas em uma análoga entoação espiritual, o Anonimo Triestino ${ }^{1}$ selará a paixão do protagonista de Segreto (Einaudi, 1961)".

\footnotetext{
${ }^{1}$ Pseudônimo de Giorgio Voghera (1908-1999), escritor italiano nascido em Trieste. (n. t.)
} 